\title{
Treatment Vehicle Volume
}

National Cancer Institute

\section{Source}

National Cancer Institute. Treatment Vehicle Volume. NCI Thesaurus. Code C93697.

The amount of three dimensional space (including units of measure) occupied by the treatment vehicle used. 